\title{
Mellem Skylla og Charybdis \\ - træk af legalitetsprincippets historie i dansk strafferet
}

\author{
Morten Kjoer, adjunkt, Syddansk Universitet
}

\begin{abstract}
This article deals with the history of the principle of legality in Danish criminal law. The principle of legality is a relatively new invention and was first introduced with the criminal code of $1866 \$ 1$. Before that, courts were given broad discretion in criminal cases. This discretion must be viewed as the logical consequence of the lack of a comprehensive and systematic criminal code such as that first issued in 1866 where it replaced the sixth book in the National Law of Denmark 1683. With the promulgation of a new systematic criminal code it was possible to introduce the principle of legality in Danish criminal law in 1866. While the principle of legality was designed to secure the predictability of the criminal law, measures were also taken in order to secure flexibility in the application of the code by the courts. The often casuistic definitions of the criminal offenses in the National Law of Denmark were thus replaced by abstract definitions and the courts were generally left with a wide margin of discretion when it came to questions of punishment. The criminal code of 1866 was thus built on a compromise between legality and flexibility.
\end{abstract}

\section{Introduktion}

»Straf kan kun pålægges for et forhold, hvis strafbarhed er hjemlet ved lov, eller ganske må ligestilles med et sådant. $\ll^{1}$

Det strafferetlige legalitetsprincip er som den første bestemmelse i straffeloven indgangen til strafferetten i dag, dets placering og indhold understreger kravets fundamentale karakter. ${ }^{2}$ I det lange retshistoriske perspektiv er bestemmelsen ikke desto mindre forholdsvis ny. Legalitetsprincippet blev først en del af strafferetten med straffeloven $1866 \S 1{ }^{3}$ Bestemmelsen blev afløst af straffeloven 1930 $\S 1$, der stadig er gældende. ${ }^{4}$ Denne artikel ser på det strafferetlige legalitetsprincips historie i dansk strafferet. Det gøres med fokus på den historiske udvikling frem mod indførslen af straffeloven 1866. Her lægges der vægt på, hvordan strafferetten fungerede uden et legalitetsprincip, begrundelsen for legalitetsprincippets indførsel i 1866 og dets sammenhæng med strafferettens udformning. På denne 
baggrund slutter artiklen med en diskussion af den svære balancegang mellem at sikre fleksibilitet og legalitet i strafferetten.

\section{Straf uden lov}

I 1537 afsagde den daværende øverste domstol i Danmark, Rettertinget, der bestod af kongen og rigsrådet, to vigtige domme. ${ }^{5}$ I den ene blev en ugift mand og en gift kvinde dømt til døden, fordi de havde begået hor sammen. I den anden blev en mand, der havde indgået ægteskab nummer to uden at være blevet skilt fra sin første hustru, dømt »for slig gerning at være i vor nåde og unåde « - en potentiel dødsdom, der overlod det til kongen at fastsætte den endelige straf. ${ }^{6}$ Mens straffen og synet på de pågældende forbrydelser kan forekomme meget fremmedartet for en jurist i dag, er det interessante her hjemlen, som Rettertinget anvendte i de to domme. Den første dom anførte som hjemmel i en margin i domsprotokollen »kejserloven«, der sandsynligvis var en henvisning til tysk strafferet. I den anden dom opgav Rettertinget at finde en hjemmel og nøjedes i stedet med at fastsætte, at kongen skulle straffe manden »efter den skik og ordinans, som der på gøres skal« - dvs. efter den lov, der efterfølgende skulle udstedes. I de to domme blev der således idømt dødsstraf eller en potentiel dødsstraf efter henholdsvis en udenlandsk og en fremtidig lov. Dommene illustrerer med al tydelighed, at der ikke gjaldt et strafferetligt legalitetsprincip i Danmark på dette tidspunkt. ${ }^{7}$ Eller som retshistorikeren Henning Matzen sammenfatter det:

»Man dømte aabenbart [...] efter et mere vilkaarligt Skjøn over, om vedkommende Gjerning ifølge sin egen Beskaffenhed egnede sig til Straf, og da hvilken, $\varkappa^{8}$

Manglen på et legalitetsprincip var ikke noget nyt i 1537. Et sådant fandtes heller ikke i landskabslovene eller den øvrige lovgivning. Perioden fra 1536 til 1683 er ikke desto mindre velegnet til at illustrere en strafferet uden et legalitetsprincip. Det skyldes, at det først for alvor er for denne periode, at der er bevaret praksis, der kan illustrere strafferettens praktiske anvendelse. Samtidig var periodens strafferet præget af forandringerne efter Reformationen i 1536. Før Reformationen havde en lang række forbrydelser som kirkelige forbrydelser og sædelighedsforbrydelser hørt under den katolske kirke, der havde haft sig eget retssystem og domstole. Efter Reformationen var de blevet overført til staten, og der var således adskillige forbrydelser, som skulle optages i den verdslige lovgivning. Tiden mellem Reformationen og udstedelsen af Danske Lov 1683, der kodificerede straffelovgivningen i sjette bog, kan betragtes som en proces, hvor disse forbrydelser en for en blev optaget i verdslig strafferet, indtil der med Danske Lov var kommet 
lovhjemmel til at straffe dem alle. ${ }^{9}$ Blodskam (incest) blev først med Forordning 16. juni $1637 \S 2$ udtømmende reguleret i lovgivning, ${ }^{10}$ mens polygami - trods løftet om eksplicit lovgivning i dommen fra 1537 - og sodomi (bestialitet og homoseksualitet) først blev omfattet af udtrykkelig lovgivning med Danske Lov 1683. ${ }^{11}$ Fraværet af et strafferetligt legalitetsprincip medførte ikke straffrihed, forbrydelser som de nævnte kunne og blev straffet, før de blev optaget i straffelovgivningen. Straffen for sådanne forbrydelser blev i stedet overladt til praksis.

For strafferetten betød det, at praksis blev en vigtig kilde som supplement til lovgivningen. Her kom domstolene med Rettertinget i spidsen til at spille en vigtig rolle. I dommen om hor var Rettertinget da også opmærksom på betydningen af sagen. Dommen blev udformet som et præjudikat, der understregede, at straffen for hor blev fastsat for, »at det her efter skulle vides at straffes for slige uhyrlige gerninger«. Rettertinget var dermed fuldt ud bevidst om, at den i dette tilfælde udøvende en retsskabende virksomhed inden for strafferetten.

Manglen på et legalitetsprincip medførte en stor grad af fleksibilitet for retsanvendelsen, hvor straffen således kunne fastsættes ud fra friere overvejelser om forbrydelsens karakter. Ud over undtagelsesvis brug af udenlandsk strafferet ${ }^{12}$ ses også eksempler på, at straffereglerne i mosaisk ret fra Mosebøgerne i Det Gamle Testamente blev anvendt. Det byggede på en overbevisning om, at de ikke kun gjaldt israelitterne, men var udtryk for naturret. ${ }^{13}$ I 1628 blev den adelige Ellen Lange således med hjemmel i Guds lov dømt til døden af Rettertinget for blodskam med sin bror. ${ }^{14}$ Den naturretlige tanke om en ret, der står over den positivt fastsatte ret, står således $\mathrm{i}$ et vist omfang i kontrast til et strafferetligt legalitetsprincip. Når datidens kristne naturret således fastslog, at regler i mosaisk ret kunne være udtryk for naturret og gjaldt alle, måtte de kunne anvendes i strafferetten, uanset om der fandtes en positiv lovhjemmel. Da det strafferetlige legalitetsprincip omvendt blev indført i dansk strafferet i 1866, var retten i langt højere grad blevet sekulariseret, og brugen af mosaisk ret som naturret var opgivet som følge af oplysningstidens strafferetlige reformer i Danmark. ${ }^{15}$

Det er en klassisk drøftelse i dansk retshistorie, om Danmark i 1500- og 1600tallet kan betragtes som et retssamfund. ${ }^{16}$ Manglen på et strafferetligt legalitetsprincip taler imod dette synspunkt. Hvor datidens strafferet dermed var undergivet en principiel form for usikkerhed, skal usikkerheden heller ikke overdrives. For langt de fleste af de forbrydelser, der blev overladt til praksis, var det forudsigeligt, at forholdet ville blive straffet, og hvor straffen fulgte af en etableret praksis, måtte også den være forudsigelig. Forbrydelser som i de ovennævnte domme udgjorde samtidig et brud på Guds bud, og befolkningen kunne derfor gennem forkyndelsen i kirkerne indskærpes handlingernes karakter af synd og forbrydel- 
ser. I de nævnte domme har det således næppe været overraskende, at forholdene ville blive straffet. Bigamisten tilstod da også forholdet og anmodede afslutningsvist om, at kongen ville være nådig mod ham.

Når det gjaldt straffen, var det langt fra altid en fordel, at der ikke var eksplicit lovgivning. Rettertingets domme og dets præmisser kunne være så vidtgående, at de senere måtte modificeres af lovgivningen.Dødsstraffen for hor efter Rettertingets præjudikat blev inkorporeret i lovgivningen med Reces $1537 \S 8$. Efter to år blev straffen formildet med Reces 1539 § 3, så dødsstraffen først skulle anvendes ved det tredje hor. Det blev legitimeret med befolkningens klager. ${ }^{17}$ I 1603 dømte Rettertinget to adelige til døden for blodskam uden klar hjemmel. ${ }^{18} \mathrm{Ud}$ fra Rettertingets præmisser måtte samtlige forhold, der blev betragtet som blodskam, straffes med døden. Forbuddet mod blodskam dækkede dengang slægt- og svogerskab til og med 3. led (grandfætre-grandkusiner), og de involverede adelige havde været besvogret i 2. led. Et så vidtgående synspunkt blev ikke opretholdt i lovgivning. Efter Forordning 6. april 1610 blev dødsstraffen kun forudsat anvendt i de to første led, og efter Forordning 16. juni 1637 blev dødsstraffen for 2. led også ophævet. Omvendt fungerede udtrykkelig lovgivning som et værn mod hårdere straffe. ${ }^{19}$ I en sag, hvor kongen følte sig særligt fornærmet af, at hans kammerjunker havde gået i seng med en af dronningens tjenestepiger, blev der på kongens vegne nedlagt påstand om dødsstraf. Det var der ikke hjemmel til i lovgivningen, der eksplicit havde reguleret et sådant forhold, og selvom de involverede fik alvorlige straffe, blev dødsstraffen ikke anvendt. ${ }^{20}$

I perioden mellem Reformationen og Danske Lov blev der ikke sondret skarpt mellem lovgivning og den faste retspraksis. Flere gange ses henvisninger til, at en forbrydelse skulle straffes efter »loven« evt. i kombination med »recessen« eller »Håndfæstningen«. Det betød, at forbrydelsen skulle straffes efter gældende ret, og det forudsatte ikke nødvendigvis, at den var omfattet af udtrykkelig lovgivning. ${ }^{21}$ Forordning 12 . oktober 1617 om trolddom fastsatte i $\S 2$, at folk, der indgik en pagt med Djævelen, skulle straffes efter »loven og recessen«. En sådan udtrykkelig lov fandtes ikke, men efter fast praksis var straffen dødsstraf i form af bålstraf. På samme måde henviste teologerne fra Københavns Universitet i en betænkning fra 1561 til, at bålstraf for blodskam var hjemlet $\mathrm{i} »$ vor danske lov«. ${ }^{22}$ En sådan lov blev først udstedt med Forordning 1637. Datidens strafferet vidner således om sædvanerettens vigtige rolle, der havde afgørende betydning for strafferetten.

Set fra centraladministrationens synspunkt kunne der også være fordele forbundet med at undlade at lovgive om forbrydelser. Det medførte dels fleksibilitet i retsanvendelsen, og nogle forbrydelser kunne måske være så forargelige eller 
tabuiserede, at det var bedst ikke at nævne dem i lovgivningen. Et eksempel på en sådan forbrydelse er sodomi, som først blev nævnt i Danske Lov 1683, og selv da blev den defineret abstrakt som omgængelse imod naturen, jf. DL 6-13-15. ${ }^{23}$

\section{Danske Lov og de arbitrære straffe}

Danske Lov 1683 sætter et vigtigt skel i strafferetshistorien, da den kodificerede strafferetten i sjette bog: »Om Misgerninger«. Her blev den eksisterende strafferet samlet $\mathrm{i}$ en bog og suppleret med nye bestemmelser. Som kodifikation byggede den både på den tidligere lovgivning og praksis. I Stig Iuuls udgave af Danske Lov er bestemmelserne forsynet med kildeangivelser, hvor de har bygget på ældre ret. Det er en effektiv markør af betydningen af retspraksis som supplement til straffelovgivningen. 16 bestemmelser i sjette bog byggede på retspraksis. ${ }^{24} \mathrm{De}$ dækkede over alvorlige forbrydelser, der kunne medføre straffe fra bøder, fængsel og legemsstraffe til dødsstraffe i form af drukning, halshugning eller bålstraf. Sjette bog indeholdt ligesom tidligere lovgivning ikke noget strafferetligt legalitetsprincip. Selvom den samlede strafferetten i en bog og kodificerede flere af de i praksis udviklede straffe, forhindrede den ikke, at domstolene fortsat måtte dømme ud fra friere overvejelser i strafferetten. Bestemmelsernes ofte kasuistiske udformning, og da der kun var nævnt et begrænset antal forbrydelser, skabte fortsat et behov for, at domstolene i praksis idømte arbitrære straffe uden udtrykkelig hjemmel i lov. Selvom Danske Lov løbende blev suppleret med ny straffelovgivning, måtte domstolene løbende indtil straffeloven 1866 idømme arbitrære straffe. $^{25}$

Tidens strafferetlige strømninger, der pegede frem mod legalitetsprincippet, var ikke ukendte i Danmark. Montesquieus (1689-1755) teori om magtens tredeling lå meget tæt på et strafferetligt legalitetsprincip, da det var domstolene, der skulle idømme straffe og gøre det som »lovens mund « uden at udøve et skøn. ${ }^{26}$ I Danmark blev Montesquieus tanker brugt af en af enevældens mest centrale embedsmænd, generalprokurør Henrik Stampe (1713-1789). I en af sine mest berømte erklæringer fremhævede han i 1767, at det var domstolene, som skulle »bestemme straffen, ved at anvende straffelovene på den forøvede misgerning « ${ }^{27}$ Ligeledes vendte han sig i samme erklæring skarpt imod at give en straffelov tilbagevirkende kraft. ${ }^{28}$

En af de vigtigste forfægtere for et strafferetligt legalitetsprincip var den tyske jurist Paul Johann Anselm von Feuerbach (1775-1833). Han opstillede et strafferetligt legalitetsprincip nulla poena sine lege. Legalitetsprincippet var tæt knyttet til hans teori om psykologisk tvang og straffelovgivningens generalpræventive virkning. ${ }^{29}$ I Danmark blev hans teori indgående drøftet af Anders Sandøe Ørsted 
(1778-1860), der i stedet for et legalitetsprincip satte de naturlige forbrydelser. Det var en række forbrydelser, som måtte straffes, uanset at de ikke var omfattet af straffelovgivning. ${ }^{30}$ I »Over de første Grundregler for Straffelovgivningen« (1817) drøftede han indgående spørgsmålet om legalitetsprincip. ${ }^{31}$ Her henviser han udtrykkeligt til nødvendigheden af at afvise et legalitetsprincip i de mange stater, der ikke har nyere straffelove. ${ }^{32}$ I stedet fremførte han teorien om naturlige forbrydelser, der netop ifølge deres natur var forudsigelige for befolkningen: »En naturlig Misgjernings Strafbarhed kan ikke være nogen, der ejer sund Sans, ubekendt, «. ${ }^{33}$ Ørsteds modstand mod et strafferetligt legalitetsprincip må især ses på baggrund af Danske Lovs usystematiske karakter. ${ }^{34}$ I et vigtigt afsnit demonstrerede Ørsted med eksempler fra Danske Lov, at det var nødvendigt, at den blev suppleret med naturlige forbrydelser, der kunne straffes uden lovhjemmel. ${ }^{35}$

\section{Ingen straf uden lov}

Med straffeloven 1866 blev legalitetsprincippet for første gang en del af strafferetten:

»§ 1. Ingen kan straffes efter denne Lov, medmindre han har gjort sig skyldig i et Forhold, der gaar ind under en af de i Loven givne Straffebestemmelser, eller ganske maa sættes ved Siden af en i samme som Forbrydelse betegnet Handling.«

En ny straffelov havde længe været ønsket. ${ }^{36}$ I 1859 havde en kommission afsluttet sit arbejde med et udkast til en straffelov. ${ }^{37}$ Dette arbejde blev fortsat med nedsættelsen af en ny kommission samme år, der udarbejde et nyt udkast i $1864,{ }^{38}$ som Landstinget året efter afgav en grundig betænkning over. ${ }^{39}$ Straffeloven blev vedtaget i Rigsdagen i 1866 og udstedt 10. februar 1866. I 1859udkastet var $\S 1$ afffattet lidt anderledes og indeholdt ikke mulighed for den fuldstændige lovanalogi. Mens udvidende fortolkninger ikke skulle udelukkes, vendte kommissionen sig i motiverne klart imod analogislutninger:

»Derimod udelukker $\S 1$ Analogiseren saavel fra en enkelt bestemt Lovbestemmelse (Lovanalogi) som fra Lovens Aand og Grundsætninger i Almindelighed (Lovgivnings- eller Retsanalogi), hvorved man støttende sig paa Raisonnoment om, hvad Lovgiveren maatte have tænkt og villet, dersom han havde være conseqvent, gaaer ud ikke blot over Lovens Ord, men over dens Tanke og altsaa over dens virkelige Indhold. ${ }^{40}$

Det blev afslutningsvist medgivet, at det kunne være svært at trække grænsen mellem en udvidende fortolkning og en lovanalogi. Legalitetsprincippet blev be- 
grundet i den nye systematiske straffelovs fuldstændighed, der skulle beskytte borgerne:

»naar der gives en almindelig Lov angaaende Forbrydelser og Straffe, at den da ogsaa fuldstændigen udtømmer sit Stof, saa at Borgerne ikke skulle udsættes for, at det skal komme til at beroe paa den enkelte Dommers subjective og derfor altid mere eller mindre vilkaarlige Anskuelse om, hvad der vil være en conseqvent videre Anvendelse af Loven og dens Aand paa Tilfælde, som Loven selv ikke har havt for Øie, om de for en begaaet Handling skulle straffes og hvorledes de skulle straffes $\aleph^{41}$

Ved at udstede en ny, systematisk straffelov fjernedes grunden til de tidligere arbitrære straffedomme, der ifølge udvalget primært skyldtes »den hidtilværende danske Strafferets eiendommelige usystematiske Beskaffenhed «. ${ }^{42}$

1864-udkastet beholdt legalitetsprincippet i $\S 1$ i en mildt ændret affattelse. Den vigtigste ændring var, at bestemmelsen nu tillod den fuldstændige lovanalogi, som blev en del af den endelige bestemmelse. Kommissionen var enig med det tidligere udvalg i, at en ny, systematisk straffelov skulle afskære den såkaldte retsanalogi, der muliggjorde at idømme straf ud fra et friere skøn, og kritiserede, at domstolene syntes at have anvendt den $» i$ temmelig stor Udtrækning og stundom noget vilkaarlig $\ll .{ }^{43}$ Derimod ville de åbne op for den fuldstændige lovanalogi, hvor tilfældet »i alle Henseender maa stilles i Klasse med og ved Siden af det i Lovbestemmelsen udtrykkelig omhandlede Tilfælde«. Her ville det ikke være betænkeligt at give domstolene denne mulighed, ligesom det blev betragtet som umuligt at udforme en straffelov sådan, at den kunne forudse alle de former, en forbrydelse kunne optræde på under den fremtidige udvikling. Det afgørende var dermed hensynet til fleksibilitet i retsanvendelsen, og at den fuldstændige lovanalogi ikke på samme måde som retsanalogien blev fundet retssikkerhedsmæssigt betænkelig.

Landstingets udvalg tilsluttede sig kommissionens betragtninger og understregede legalitetsprincippets vigtighed $i$ en systematisk straffelov:

»Maatte dette Forslag vinde Bifald, vil Loven komme til at begynde med en Udtalelse af den Sætning, at Ingen kan idømmes Straf, medmindre det Forhold, hvori han har gjort sig, falder ind under Straffelovens Bestemmelser - nulla poena sine lege.. ${ }^{44}$

Udvalget tilsluttede sig muligheden for den fuldstændige lovanalogi for at sikre fleksibilitet, og som kommissionen betragtede de det som umuligt, at lovgivningen kunne forudse alle de nævnte forbrydelsers former. Ved at sikre sig, at be- 
stemmelsen kun åbnede op for den fuldstændige lovanalogi, forhindrede de stadig vilkårlighed i strafferetten:

»Ved denne Begrænsning vil Reglen vistnok komme til et udtrykke netop det, som tilsiges, at opstille et Værn imod, at Nogen vilkaarligen skulde kunne rammes af Straffeansvar, derved at et Forhold, hvorom Straffeloven tier, skulde af Domstolene kunne belægges med Straf i Medfør af Lovgivningens Aand og Grundsætninger. Det er denne Art af Analogier, der bør bortfalde ved Vedtagelsen af en ny almindelig Straffelov. $\ll^{45}$

Legalitetsprincippet i straffeloven $1866 \S 1$ byggede således på et kompromis mellem hensynet til at sikre legalitet og fleksibilitet i straffelovgivningen. Legalitetsprincippet blev indført for at skabe forudsigelighed i strafferetten og beskytte borgerne mod vilkårlighed i retsanvendelsen - domstolenes anvendelse af den mere frie retsanalogi - og da den nye, systematiske straffelov skulle være udtømmende. På den anden side blev det oprindelige forslag om at afskære alle analogislutninger afvist. Den fuldstændige lovanalogi var ikke på samme måde retssikkerhedsmæssigt betænkelig og blev fundet nødvendig for at sikre fleksibilitet $\mathrm{i}$ strafferetten.

Straffelovens legalitetsprincip er i dag suppleret af Den Europæiske Menneskerettighedskonventions art. 7 og for områder, der falder ind under EU-retten, af Den Europæiske Unions Charter om Grundlæggende Rettigheder art. 49. Mens straffelovens $\S 1$ stadig giver mulighed for anvendelsen af den fuldstændige lovanalogi, er det tvivlsomt, om det er foreneligt, med de menneskeretlige forpligtelser, og den har formentlig kun et meget snævert anvendelsesområde i dag. ${ }^{46}$

\section{Legalitet, fleksibilitet og straffelovgivning}

Legalitetsprincippet i straffeloven $1866 \S 1$ byggede på et kompromis mellem hensynet til legalitet og fleksibilitet. Disse hensyn gør sig ikke kun gældende ved selve legalitetsprincippet, men har afgørende betydning for hele straffelovgivningens udformning. Legalitetsprincippet skal sikre legalitet i strafferetten og dermed forudsigelighed. Hvis straffelovgivningen stadig skal være fleksibel og sikre en smidig retsanvendelse og løbende tilpasning af strafferetten i praksis, stiller det krav til udformningen af den øvrige straffelovgivning. Her får særligt forbrydelsernes definition og spørgsmålet om strafferamme betydning.

Mens manglen på et legalitetsprincip i Danske Lov medførte en stor grad af fleksibilitet, var udformningen af de enkelte straffebestemmelser anderledes rigide. Straffebestemmelserne var som den tidligere straffelovgivning kasuistiske, konkret formulerede bestemmelser, som omhandlede enkelttilfælde. Samtidig var 
straffene absolut lovbestemte. Danske Lov fastsatte som udgangspunkt straffen for den enkelte forbrydelse uden mulighed for nærmere skøn, ligesom der ikke fandtes strafferammer. ${ }^{47}$ Et eksempel på en absolut lovbestemt straf er straffen for hor i DL 6-13-24. Første gang en ægtefælle begår hor, er straffen en formuestraf på bosloden, anden gang forvisning fra landsdel (f.eks. Jylland) og tredje gang dødsstraf.

I mindre omfang gav enkelte bestemmelser mulighed for et skøn. ${ }^{48}$ I sjette bog gav 14 bestemmelser i mindre omfang mulighed for at udøve et skøn ved fastsættelse af straffen f.eks. 6-4-4, der fastsatte straffen til ære, liv eller gods efter gerningens beskaffenhed. ${ }^{49}$ Mens muligheden for arbitrære straffe gav mulighed for fleksibilitet, var de lovbestemte straffe anderledes ufleksible. De blev derfor suppleret med en udbredt benådningspraksis, hvor kongen benådede de straffe, der efterhånden blev anset for utidssvarende og for hårde. Der havde også været en ofte udbredt benådningspraksis op til Danske Lov, uden at den havde sat sig spor i dens udformning. ${ }^{50}$ Fra 1700 -tallets anden halvdel og gennem 1800 -tallet blev benådninger endnu mere udbredte og gik i flere tilfælde forud for, at lovgivningen efterfølgende blev formildet. ${ }^{51}$

Denne strafferet med mulighed for arbitrære straffe, kasuistiske bestemmelser og absolutte lovbestemte straffe blev genstand for en principiel kritik i forbindelse med udformningen af 1866 straffeloven. Mens indførslen af legalitetsprincippet skulle sikre borgerne mod domstolenes ulovbestemte skøn, skulle fleksibiliteten i strafferetten samtidig sikre mod den lovbestemte kasuistik. I Landstingets betænkning er kritikken af den ældre strafferet hård: ${ }^{52}$

»Den behandler ikke Forbrydelserne paa systematisk Viis, som et udtømmende Hele, der maatte kunne give Norm for alle mødende Forhold. Den opstiller kun Regler for enkelte Arter af Forbrydelser og ofte endog kun for en enkelt forbryderisk handling, ikke at tale om, at den belægger de Forbrydelser, den har gjort til Gjenstand for Behandling, med absolut bestemte Straffe, der ikke overlade noget Valg til Dommerne. ${ }^{53}$

Loven havde således gjort det nødvendigt at »tage sin Tilflugt til Benaadningsmagten «, men også det var problematisk, da det uundgåeligt måtte medføre ulige behandling af de samme forhold og skadede »Lovens Anseelse og Magt $\ll .{ }^{54}$ En sådan situation var ifølge udvalget i strid med grundlovens ånd:

»Den Aand, der gaaer igjennem Grundloven, kan ikke tillade, at en saadan Tilstand vedbliver. ${ }{ }^{55}$ 
Samtidig øgede indførslen af legalitetsprincippet behovet for at sikre fleksibilitet i strafferetten. En kasuistisk strafferet med absolut lovbestemte straffe ville i kombination med et legalitetsprincip resultere i en meget rigid og formalistisk strafferet. Udformningen af de enkelte straffebestemmelser med et abstrakt defineret gerningsindhold og med strafferammer må derfor ses som et bevist valg, der skulle supplere legalitetsprincippet. ${ }^{56}$ På den måde søgte straffeloven 1866 på samme tid at sikre legaliteten og fleksibiliteten i strafferetten. Det første skulle sikres gennem et legalitetsprincip, det sidste gennem brugen af abstrakte definitioner og strafferammer.

Landtingets udvalg roste da også udformningen af straffeloven, definitionerne af de enkelte forbrydelser, og at straframmerne gjorde det muligt at tilpasse straffen til »hvert enkelt tilfældes krav« ${ }^{57}$ Brugen af abstrakte definitioner af de enkelte forbrydelser skete til dels på bekostning af sproglig enkelhed. Udvalget medgav derfor, at ordlyden i Danske Lov i højere grad var simpel og klar, men magtede ikke selv at foretage en gennemgribende revision af loven ud fra dette hensyn. ${ }^{58}$ F.eks. blev de kasuistiske regler DL 6-7 »Om afhug og Saar« erstattet med 18. kapitel i straffeloven $1866 » O m$ Vold paa Person og Legemsbeskadigelser«. Danske Lovs 18 bestemmelser sondrede nøjagtigt og kasuistisk mellem forskellige opregnede angreb og typer af skader såsom afhug af næse, øre, tunge, hånd, fod og finger, jf. 6-7-1, andre sår jf. 6-72, huldsår, jf. 6-7-3, sår i ansigt og hænder, jf. DL 6-7-6 og bid, jf. 6-7-13. I Straffeloven 1866 blev de erstattet med otte mere generelt formulerede bestemmelser om vold og legemsbeskadigelser. Her var $\S 200$ den almindelige straf for vold, $\S 203$ straffen for mindre sår og skade og $§ 204$ straf for lemlæstelse.

Med straffeloven 1866 gjorde brugen af strafferammer sit endegyldige indtog i dansk strafferet. Straffen for hor blev således fastsat til fængsel eller, hvis samlivet mellem ægtefællerne var ophævet eller under særligt formildende omstændigheder med bøder, jf. § 159. Straframmerne for de enkelte forbrydelser blev suppleret med de generelle udmålingsregler i kapitel seks. Her gav $\S 57$ en generel vejledning i, hvad der skulle lægges vægt på ved strafudmålingen, herunder forbrydelsens farlighed, skadens omfang og gerningsmandens subjektive forhold. Bestemmelsen skulle alene være en generel hjælp til dommerne. Som det blev fastslået i forarbejderne, var det på ingen måde hensigten, at bestemmelsen skulle indeholde en detaljeret og udtømmende opregning. ${ }^{59}$ Strafferammer var første gang blevet introduceret med den banebrydende tyveriforordning fra 1789. Forordningen byggede på principperne i oplysningstidens strafferet og sætter et skel i dansk strafferetshistorie. ${ }^{60}$ Brugen af strafferammer brød dog både med Montesquieu og den fremtrædende strafferetstænker Cesare Beccaria (1734-1794), der 
ikke levnede dommerne noget skøn i strafferetten.$^{61}$ Dermed tog forordningen det første skridt mod at introducere en generel fleksibilitet i strafferetten, som skulle udøves gennem dommernes skøn i den enkelte straffesag.

Straffeloven 1866 bygger således på en reflekteret afvejning af hensynet til at sikre legalitet og fleksibilitet i strafferetten. Det kan også betragtes ud fra et magtfordelingssynspunkt. Lovens rolle skulle styrkes med en ny systematisk straffelov med et legalitetsprincip. Den udøvende magts rolle skulle begrænses ved at fjerne behovet for de hyppige benådninger, der underminerede lovgivningens autoritet. Den dømmende magts rolle skulle forandres. Domstolenes rolle skulle på samme tid begrænses ved indførslen af et legalitetsprincip og udvides ved den konsekvente brug af strafferammer. Det lovbestemte skøn skulle afløse det ulovbestemte. Det var en opgave, som domstolene var klar til. I 1736 blev der med eksamensforordningen stillet krav til dommernes juridiske kundskaber, og fra 1821 skulle alle dommere have en juridisk eksamen. ${ }^{62}$ Brugen af strafferammer og betroelsen af et lovbestemt skøn til domstolene falder således sammen med opbyggelsen af en professionel, juridisk uddannet dommerstand.

Straffeloven 1866 kan betragtes som et barn af grundloven 1849, hvor bestemmelsen om magtens tredeling kan ses som en forudsætning for indførslen af legalitetsprincippet. ${ }^{63}$ Landstingets udvalg henviste direkte til grundloven som argument for at styrke lovens autoritet i strafferetten. Samtidig henviste de til løfteparagraffen om nævningers medvirken i straffesager. ${ }^{64}$ I rosen af straffebestemmelsernes udformning fremhævede de, at der var lagt vægt på, at deres:

»Indhold maatte være forstaaeligt for Lægmand saavelsom for Juristen, og som saaledes kunde tjene til Veiledning for Nævningerne, der i en nær Fremtid ville kaldes til at sige Dom over Medborgeres Liv og Velfærd, og for Enhver der under Landets frie Forfatning har Øie og Interesse for Lovene og deres Anvendelse. ${ }^{65}$

Mens Danske Lovs sjette bog var et barn af enevælden og kodificerede strafferetten, var straffeloven 1866 et barn af grundloven og kan betragtes som den frie forfatnings strafferet.

I 1951 udråbte retshistorikeren Stig Iuul tyveriforordningen fra 1789 som et skel i strafferetshistorien. I 2016 fejrede straffeloven 1866 sit 150-års jubilæum, og det kan overvejes, om det i dag ikke er rigtigere at flytte dette skel frem til 1866. Straffeloven 1866 erstattede sjette bog i Danske Lov og transformerede strafferetten på en afgørende måde. Dens grundprincipper er stadig gældende i dag. Straffeloven 1930 videreførte legalitetsprincippet $\mathrm{i} 1$ og byggede fortsat på abstrakte definitioner af forbrydelsernes gerningsindhold og brugen af straffe- 
rammer, som blev udvidet. ${ }^{66}$ Kompromisset med at sikre både legalitet og fleksibilitet i straffelovgivningen afspejles dermed fortsat i straffelovgivningen i dag. Det afspejles også i domspraksis. Højesteret henviste således i sin dom fra 2010 om fastsættelse af straf for drab på ægtefælle eller samlever til sin opgave med at fastsætte straffen inden for straffelovens grænser:

»det er Højesterets opgave at sikre, at strafniveauet tilpasses samfundsforholdene ved angivelse af retningslinjer for udmålingen inden for lovens strafferamme «. ${ }^{67}$

\section{Mellem Skylla og Charybdis}

»Klagende stævned vi ind $\mathrm{i}$ den snævre og trange passage.

Her lå Skylla på lur og overfor gurgled Charybdis. « ${ }^{68}$

Straffeloven 1866 byggede på et kompromis mellem hensynet til legalitet og fleksibilitet. På samme tid forsøgte lovgiver at undgå to onder - det ulovbestemte skøn og den lovbestemte kasuistik. De kan betragtes som straffelovgivningens Skylla og Charybdis. På sin lange og farefulde hjemtur måtte sagnhelten Odysseus navigere sit skib mellem de to uhyrer Skylla og Charybids. For at undgå forliset valgte Odysseus ultimativt det mindste onde og sejlede tættest på Skylla, der nøjedes med at spise seks af besætningens medlemmer. ${ }^{69}$ Da Odysseus spurgte, om der ikke fandtes en måde at undgå Charybdis og samtidig bekæmpe Skylla, blev han skarpt irettesat af gudinden Kirke for sin frækhed, og det var da også umuligt. Måske gør det samme sig gældende for straffelovgivningen. Hvis det ikke er muligt at finde det gyldne snit mellem hensynene til fleksibilitet eller legalitet, ${ }^{70}$ må straffelovgivningen i stedet nøjes med at navigere mellem dens to onder - det ulovbestemte skøn og den lovbestemte kasuistik - og bestandigt søge det mindste onde. Det er da også en svær balancegang. Hvis lovgivningen ikke overlader nogen fleksibilitet til domstolene, bliver lovgivningen rigid og formalistisk. Hvis lovgivningen overlader et for stort skøn til domstolene, kan det underminere legalitetsprincippet og svække forudsigeligheden. Endelig kan det overvejes, om der kan skabes fleksibilitet ved som under retsopgøret efter besættelsen at give straffelovgivningen tilbagevirkende kraft - men så er der tale om et helt andet uhyre. $^{71}$

Straffelovgivningens to onder viser sig fortsat i diskussionen af straffelovgivningens udformning. Straffelovgivningen overlader fortsat domstolene et vidt skøn. På baggrund af en betænkning fra Straffelovrådet i 2002 blev udmålingsreglerne i $\S \S 80-83$ revideret. Den generelle udmålingsregel i $\S 80$ betoner således i dag, at straffastsættelsen skal ske »under hensyntagen til ensartethed i rets- 
anvendelsen «. ${ }^{72}$ Herefter følger de nærmere hensyn i $\S \S 81-83$. Bestemmelserne overlader stadig dommerne »et ganske vidt skøn med hensyn til strafniveauet . $^{73}$ Der kan således stadig opstå »problemer med forudsigeligheden og ensartetheden « i strafudmålingen. ${ }^{74}$ Omvendt ses der også tendenser i retningen af en delvis tilbagevenden til kasuistisk straffelovgivning, hvor lovgivningen går meget langt i retningen af at regulere domstolenes skøn. ${ }^{75}$ Begge straffelovgivningens onder påvirker forholdet mellem lovgiver og domstole. Straffelovrådets betænkning om strafudmåling fra 2012 havde derfor den meget passende titel: »Strafudmåling samspillet mellem lovgiver og domstole $\ll^{76}$ Betænkningen viser tydeligt, hvordan de ovennævnte onder stadig er relevante og diskuteres. ${ }^{77}$ På et punkt er betænkningen i særdeleshed forbilledligt kort og klar. I kapitel 5, afsnit 3.5, drøftes kort og »for fuldstændighedens skyld« lovbestemte straffe, som udvalget vender sig særdeles skarpt imod:

»Lovbestemmelser, der direkte fastsætter, hvad straffen for en forbrydelse skal fastsættes til, er udtryk for en fuldstændig fravigelse af det strafferammesystem, som i en meget lang årrække har været anvendt i dansk strafferet. ${ }^{78}$

Hensynene bag udformningen af straffeloven 1866 træder dermed stadig klart frem i dag. Det lykkedes næppe straffeloven 1866 helt at undgå både Skylla og Charybdis, men dens udformning og forarbejder viser, at lovgiver var opmærksom på dem og efter bedste evne forsøgte at undgå dem. De grundlæggende hensyn bag udformningen af straffeloven 1866 fremstår derfor ikke som forældede. Indførslen af et strafferetligt legalitetsprincip var en milepæl for strafferetten, og dens brug af strafferammer og abstrakt definerede gerningsindhold peger frem mod både indretningen og diskussionen af straffelovgivningen i dag.

\section{Noter}

1. Straffeloven $\S 1$, 1. pkt., LBK 1052 af 04/07/2016. Tak til lektor Birgit Feldtmann (Aalborg Universitet) og lektor Helle Vogt (Københavns Universitet) for kommentarer til artiklen.

2. Jf. hertil § 2, der udstrækker det til alle strafbare forhold, medmindre andet er bestemt.

3. Almindelig borgerlig Straffelov 10. februar 1866, efter udgaven i Samling af Love og Anordninger 1865-69, København 1870, s. 60-113.

4. Borgerlig Straffelov, nr. 126 af 15. april 1930, efter udgaven i Samling af Love, Anordninger ... for Aaret 1930. Afdeling A, København, s. 406-486.

5. For en nærmere analyse af dommene se Morten Kjær: Guds og øvrigheds straf. Centralmagt og scedelighed i Danmark-Norge 1536-1648, ph.d.-afhandling, Syddansk Universitet 2016, s. 7-8, 97-100 og 101-2. 
6. Rettertinget 15. april 1537 og 2. august 1537 efter udgaverne i Danske Domme 1375-1662. De private Domssamlinger I, København 1978, nr. 78 og 87. De ældste citater er af hensyn til læsevenligheden moderniseret.

7. Stig Iuul: »Den gamle danske strafferet og dens udvikling indtil slutningen af det 18. århundrede«, i Leif Beckman og Herluf Petersen (red.): Kampen mod ForbrydelsenI, Emil Wienes Forlag 1951, s. 239-294, s. 264, Poul Johs. Jørgensen: Dansk Strafferet fra Reformationen til Danske Lov, Jurist- og Økonomforbundets Forlag 2007, s. 101-103.

8. Henning Matzen: Forelcesninger over den danske Retshistorie. Offentlig Ret. III. Strafferet, J.H. Schultz 1895, s. 34, jf. s. 33-35.

9. Jørgensen: Dansk Strafferet, 2007, s. 46-47 og 101 og Morten Kjær og Helle Vogt: »Udi krigen at lade sig bruge «, 2016, under udgivelse.

10. For lovgivning fra Den koldingske Reces 1558 indtil 1660 henvises til udgaven hos V.A. Secher (udg.): Corpus constitutionum Danice. Forordninger, Recesser og andre kongelige Breve, Danmarks Lovgivning vedkommende 1558-1660, 6. bind, Selskabet for Udgivelse af Kilder til Dansk Historie 1887-1918.

11. DL 6-13-15 og 6-13-23, efter udgaven i Kong Christian den femtes Danske Lov, Stig Iuul (red.), G.E.C. Gads Forlag 1949.

12. Stig Iuul: »Den gamle danske strafferet«, 1951, s. 264.

13. Se Kjær: Guds og øvrigheds straf, 2016, s. 94-95, 166, 300 og 302-4.

14. Rettertingsdom 10.01.1628, jf. Kongens Retterting 1537-1660. Bind 2, 2003, nr. 4082.

15. Iuul: »Den gamle danske strafferet $\ll, 1951$, s. 289-90.

16. Se Helle Vogt: "»»Likewise No one shall be tortured. « The use of judicial torture in early modern Denmark«, i Scandinavian Journal of History, vol. 39, no. 1, 2014, s. 78-99, s. 9192.

17. Henvisninger til lovgivning fra 1523-1558 er til udgaverne i Aage Andersen (udg.): Den danske rigslovgivning 1523-1588, Det danske sprog- og litteraturselskab 2015.

18. 21.06.1603 og 27.06.1603, dommene er trykt i Samling af Kongens Rettertings Domme 1595-1614, bind 1, 1886, s. 431-33 og 439-41, se herom Kjær: Guds og øvrigheds straf, 2016, s. 196-98.

19. Kjær: Guds og øvrigheds straf, 2016, s. 208.

20. 15.10.1599, Samling af Kongens Rettertings Domme 1595-1614, bind 1, 1886, s. 275-76.

21. Henning Matzen: Forelcesninger over den danske Retshistorie. Indledning. Retskilder, J.H. Schultz 1897, s. 67, Jørgensen: Dansks Strafferet, 2007, s. 367 og Kjær: Guds og øvrigheds straf, 2016, s. 23.

22. 02.02.1561, Diplomatarium Islandicum, XIII, nr. 428, art XX.

23. Kjær 2016, Guds og øvrigheds straf, 2016, s. 10-11, 141 og 313.

24. DL 6-4-17, 6-5-7, 6-6-7, 6-6-12 (delvist), 6-9-4, 6-12-3 (nødværgeregel), 6-12-6 (nødværgeregel), 6-13-6, 6-13-15, 6-13-25, 6-14-7, 6-21-4 (delvist), 6-21-8 og 6-21-8. Hertil kommer 6-1-9 (delvist) og 6-5-3, der også må antages at bygge på praksis, jf. 26.04.1625, Kancelliets Brevbøger vedrørende Danmarks indre Forhold, 1624-1626, L. Laursen (udg.), København 1925, s. 380-81.

25. Iuul: »Den gamle danske strafferet«, 1951, s. 291.

26. Trine Baumbach: Det strafferetlige legalitetsprincip, Jurist- og Økonomforbundets Forlag 2008, s. 30-31. 
27. Erklæring 18.12.1767, trykt i Ditlev Tamm og Morten Kjær: Henrik Stampe. Enevaeldens menneskelige ansigt, Jurist- og Økonomforbundets Forlag 2013, s. 74-78, s. 76.

28. Ibid., s. 75 .

29. Baumbach: Det strafferetlige legalitetsprincip 2008, s. 142-44.

30. Ibid, s. 144 og Stig Iuul: »Den danske strafferets udvikling i tiden efter ca. $1800 \ll$, i Leif Beckman og Herluf Petersen (red.): Kampen mod forbrydelsen II, Emil Wienes Forlag 1952, s. 11-52, s. 35.

31. Anders Sandøe Ørsted: Over de første Grundregler for Straffelovgivningen«, i Troels G. Jørgensen: Anders Sandøe Ørsted. Skrifte r i Udvalg. Strafferetlige Skrifter. Første Afdeling, Gyldendalske Boghandel 1931, s. 80-327, se s. 134-45.

32. Ibid., s. 134-35.

33. Ibid., s. 138.

34. Baumbach: Det strafferetlige legalitetsprincip 2008, s. 146 og Iuul: »Den danske strafferets udvikling «, 1952, s. 35 .

35. Ibid, s. 138-39.

36. Stig Iuul: »Den danske strafferets udvikling«, 1952, s. 42-43.

37. Foreløbigt Udkast til Lov om Forbrydelser, J.H. Schultz 1859.

38. Udkast til Straffelovbog for Danmark med tilhørende Motiver. Udarbeidet af den allerhøeiste Kommissorium af 22de Februar 1859 dertil anordnede Kommission, J.H. Schultz 1864.

39. Betcenkning over Lovudkastet til Straffelov for Kongeriget Danmark. Afgiven af den Landsthinget nedsatte Udvalg den 18de Januar 1865, København 1865.

40. Foreløbigt Udkast til Lov om Forbrydelser, 1859, motiverne s. 4.

41. Ibid.

42. Ibid.

43. Udkast til Straffelovbog for Danmark, 1864, motiver, s. 8.

44. Betcenkning over Lovudkastet til Straffelov, 1865, s. 8-9.

45. Ibid. s. 9.

46. Vagn Greve: Det strafferetlige ansvar, Jurist- og Økonomforbundets Forlag, 2. udg. 2004, s. 87 og Birgit Feldtmann: »»)Ingen straf uden lov« - gælder princippet også i Danmark?«, i Bent Iversen (red): Juridiske Emner ved Syddansk Universitet, Jurist- og Økonomforbundets Forlag 2003, s. 50-63, s. 55, se hertil Konov v. Latvia nr. 36376/04, præmis 185-187, der i præmis 185 udtrykkeligt nævner analogi som en mulig overtrædelse af art. 7.

47. Iuul: »Den danske strafferets udvikling«, 1952, s. 22, Stig Iuul: Lov og Ret $i$ Danmark, 2. udg., Claus Ulrich (rev.), Københavns Universitets Fond til Tilvejebringelse af Læremidler 1969, s. 125-26.

48. Thomas Elholm: 8:13 om bøder og proportionalitet $i$ specialstrafferetten, Jurist- og Økonomforbundets Forlag 2010, s. 72, note 2.

49. DL 6-4-4, 6-4-12, 6-4-15, 6-4-16, 6-5-7, 6-7-13, 6-7-18, 6-8-6, 6-9-19, 6-10-2, 6-11-14, 613-3, 6-13-8 og 6-21-3.

50. Se f.eks. Kjær: Guds og øvrigheds straf, 2016, s. 315-17.

51. Iuul: »Den danske strafferets udvikling«, 1952, s. 19 og 22-23.

52. Dog med indledningsvis ros af Danske Lov, jf. Betcenkning over Lovudkastet til Straffelov, 1865, s. 3 .

53. Ibid., s. 3. 
54. Ibid., s. 4.

55. Ibid., s. 5

56. Iuul: Lov og Ret i Danmark, 1969, s. 126-29.

57. Betcenkning over Lovudkastet til Straffelov, 1865, s. 5-6.

58. Ibid., s. 7-8.

59. Udkast til Straffelovbog for Danmark 1864, s. 86, se hertil Elholm: 8:13, 2010, s. 76.

60. Se Iuul: »Den gamle danske strafferet«, 1951, s. 292-94.

61. Se Ditlev Tamm, Retshistorie. Danmark - Europa - globale perspektiver, Jurist- og Økonomforbundetsforlag, 2. udg. 2009, s. 290 om forholdet til Beccarias teori.

62. Ibid., s. 250-51 og 261-69.

63. Baumbach: Det strafferetlige legalitetsprincip, 2008, s. 149-150, jf. grundloven $1849 \S 2$, efter udgaven på http://danmarkshistorien.dk/leksikon-og-kilder/vis/materiale/danmarksriges-grundlov-af-5-juni-1849-junigrundloven/ tilgået 28.12.2016.

64. Grundloven 1849 § 79, 2. pkt.

65. Betcenkning over Lovudkastet til Straffelov, 1865, s. 7.

66. Elholm: 8:13, 2010, s. 81 .

67. U.2010.119H, s. 148.

68. Homers Odyssé, Otto Steen Due (ovs.), Gyldendal, 2. udg. 2002, s. 229.

69. Ibid., s. 224-26 og 229-30.

70. Smh. Elholm: 8:13, 2010, s. 15 om proportionalitet i strafferetten.

71. Lov nr. 259 af 1. juni 1545 om Tillæg til Borgerlig Straffelov angaaende Forræderi og anden landsskadelig Virksomhed, jf. $§ 1$. Om retsopgøret se Ditlev Tamm: Retsopgøret efter bescettelsen, Jurist- og Økonomforbundets Forlag 1984.

72. Straffeloven $\S 80$, stk. 1 , LBK nr 1052 af 04/07/2016.

73. Elholm: 8:13, 2010, s. 93, smh. s. 71 og se diskussionen 84-94.

74. Ibid., s. 93.

75. Ibid., s. 71 og Torben Melchior: »Hvem bestemmer: Folketinget eller domstolene?«, U.2011B.43, s. 43. Se hertil U.2010.789H og 796H.

76. Betænkning nr. 1531, 2012.

77. Se kapitel 5, s. 129-55.

78. Ibid., s. 149. 